\title{
RESOURCE SELECTION MODELS ARE USEFUL IN PREDICTING FINE-SCALE DISTRIBUTIONS OF BLACK-FOOTED FERRETS IN PRAIRIE DOG COLONIES
}

\author{
David A. Eads 1,5 , David S. Jachowski1 ${ }^{1}$, Dean E. Biggins², Travis M. Livieri³ \\ Marc R. Matchett ${ }^{4}$, and Joshua J. Millspaugh ${ }^{1}$
}

\begin{abstract}
Wildlife-habitat relationships are often conceptualized as resource selection functions (RSFs)—models increasingly used to estimate species distributions and prioritize habitat conservation. We evaluated the predictive capabilities of 2 black-footed ferret (Mustela nigripes) RSFs developed on a 452-ha colony of black-tailed prairie dogs (Cynomys ludovicianus) in the Conata Basin, South Dakota. We used the RSFs to project the relative probability of occurrence of ferrets throughout an adjacent 227-ha colony. We evaluated performance of the RSFs using ferret space use data collected via postbreeding spotlight surveys June-October 2005-2006. In home ranges and core areas, ferrets selected the predicted "very high" and "high" occurrence categories of both RSFs. Count metrics also suggested selection of these categories; for each model in each year, approximately $81 \%$ of ferret locations occurred in areas of very high or high predicted occurrence. These results suggest usefulness of the RSFs in estimating the distribution of ferrets throughout a black-tailed prairie dog colony. The RSFs provide a fine-scale habitat assessment for ferrets that can be used to prioritize releases of ferrets and habitat restoration for prairie dogs and ferrets. A method to quickly inventory the distribution of prairie dog burrow openings would greatly facilitate application of the RSFs.
\end{abstract}

REsumen.-A menudo las relaciones entre los animales silvestres y su hábitat se conceptualizan como funciones de selección de recursos (RSFs, por sus siglas en inglés), las cuales son modelos que se usan cada vez más para estimar las distribuciones de las especies y establecer prioridades para la conservación del hábitat. Evaluamos las capacidades de predicción de dos RSFs de hurones de patas negras (Mustela nigripes) desarrolladas en una colonia de perros llaneros de cola negra (Cynomys ludovicianus) de 452 hectáreas en la Cuenca Conata, Dakota del Sur. Usamos las RSFs para proyectar la probabilidad relativa de presencia de hurones a lo largo de una colonia adyacente de 227 hectáreas. Evaluamos el desempeño de las RSFs utilizando información sobre el espacio que usan los hurones. Dicha información se recolectó durante monitoreos con reflectores en los periodos post-reproductivos de junio a octubre de 2005 y 2006. En los ámbitos hogareños y en las áreas núcleo, los hurones escogieron las categorías de incidencia Muy Alta y Alta predichas por ambas RSFs. Las medidas basadas en conteos también indicaron la selección de estas categorías; para cada modelo, en cada año, $\sim 81 \%$ de las ubicaciones de los hurones ocurrieron en áreas en las que se había predicho que su incidencia sería Muy Alta o Alta. Estos resultados sugirieron que las RSFs son útiles para estimar la distribución de hurones a lo largo de una colonia de perros llaneros de cola negra. Las RSFs brindan una evaluación del hábitat de los hurones a escala fina que puede utilizarse para priorizar la liberación de estos animales y la restauración de sus hábitats y los de los perros llaneros. Un método que permita hacer un inventario rápido de la distribución de madrigueras de perros llaneros podría facilitar mucho la aplicación de las RSFs.

Animals depend on resources within occupied habitat for survival and reproduction, which are key components of population viability. Accordingly, wildlife conservation necessitates investigation of wildlife-habitat relationships (Morrison et al. 1998). Understanding of wildlife-habitat relationships is often conceptualized in landscape models (Millspaugh and Thompson 2009). For instance, resource selection functions (RSFs; Manly et al. 2002) estimate how resources affect a species' distri- bution within study areas (Manly et al. 2002, Johnson et al. 2004). Such models might aid in evaluating habitat quality and, therefore, facilitate habitat conservation (Johnson 2001, Millspaugh and Thompson 2009). Thus, RSFs are increasingly used in conservation contexts to evaluate habitat for species of conservation concern (Millspaugh and Marzluff 2001).

RSFs, like other wildlife-habitat models, should be evaluated (Shifley et al. 2009). By evaluating RSF performance, ideally with

\footnotetext{
${ }^{1}$ Department of Fisheries and Wildlife Sciences, University of Missouri, 302 Natural Resources Building, Columbia, MO 65211. ${ }^{2}$ U.S. Geological Survey, Fort Collins Science Center, 2150 Centre Avenue, Building C, Fort Collins, CO 80526. ${ }^{3}$ Prairie Wildlife Research, Box 308, Wellington, CO 80549.

${ }^{4}$ U.S. Fish and Wildlife Service, Charles M. Russell National Wildlife Refuge, Box 110, Lewistown, MT 59457

5Present address: Graduate Degree Program in Ecology, Colorado State University, Fort Collins, CO 80523-1878. E-mail: david.eads@colostate.edu
} 
independent data (Power 1992, Conroy and Moore 2002), managers can assess the usefulness of RSFs for their intended purpose(s) (Shifley et al. 2009), in predicting species distributions, for instance. Adequate performance of a model, in regard to its intended use, suggests model utility (Rykiel 1996). When the predictive abilities of a model are high, models can be used to facilitate conservation decisions.

Wildlife-habitat models could assist in identifying and conserving habitat for the blackfooted ferret (Mustela nigripes), an endangered mustelid currently conserved via captive propagation and reintroduction to colonies of prairie dogs (Cynomys spp.; Williams et al. 1991, Miller et al. 1994, Marinari and Kreeger 2006). Current habitat evaluations mostly involve estimation of prairie dog density and then use of a bioenergetics model to estimate carrying capacity of prairie dog complexes (i.e., groups of colonies separated by $\leq 7 \mathrm{~km}$ ) and subcomplexes (i.e., colonies separated by $\leq 1.5 \mathrm{~km}$; Biggins et al. 1993, 2006c). Greater carrying capacity suggests better habitat quality; other factors (e.g., disease) are also considered before selecting reintroduction sites (Jachowski and Lockhart 2009).

Although these habitat ratings are useful in prioritizing ferret reintroductions at large scales, recent research suggests utility in increasing the resolution of habitat evaluations. As reported in studies of ferret resource selection, ferrets selected areas of colonies where densities of prairie dog burrow openings were relatively high (Biggins et al. 1985, 2006b, Livieri 2007). To model fine-scale resource selection, a resource utilization function (RUF; Jachowski et al. 2011) and RSFs (Eads et al. 2011b) were developed for black-tailed prairie dog (C. ludovicianus) habitats. If the models prove useful in predicting either the relative (RSF) or unconditional probability (RUF) of the occurrence of ferrets, the models could be used to estimate the occurrence of ferrets in areas of distinct blacktailed prairie dog colonies (hereafter prairie dog colonies), allowing for fine-scale habitat evaluations and management.

A recent evaluation of the ferret RUF demonstrated utility in predicting occurrence of ferrets and intensity of space use by ferrets (Eads et al. 2011a). The ferret RUF was derived by relating utilization distribution (UD) home ranges (Millspaugh et al. 2006) for individual ferrets to underlying resource attributes on a 227-ha prairie dog colony (SC24) in the Conata Basin, South Dakota (Jachowski et al. 2011). This RUF was evaluated using data collected on an adjacent 452-ha colony (SC07). We found that ferrets selected areas that were estimated by the RUF as "very high" and "high" predicted occurrence areas, suggesting that the RUF can be used to predict where ferrets will occur in prairie dog colonies, at least in the Conata Basin (Eads et al. 2011a).

In contrast to the RUF, the aforementioned RSFs have not yet been evaluated via independent data. At colony SC07, the ferret RSFs were derived by correlating counts of ferret locations (population level, 2007 and 2008) in cells of an $80 \times 80-\mathrm{m}$ grid system to counts of active prairie dog burrow openings in cells, distances between cell centers and the colony edge, and an interaction between these 2 variables (Eads et al. 2011b). Year-specific RSFs suggested ferrets concentrate space use where active prairie dog burrow openings are relatively abundant, particularly near colony edges. If useful, the RSFs could be used to estimate the relative occurrence of ferrets in relation to counts of active burrow openings in cells at varying distances from colony edges. This approach contrasts with the RUF approach, which estimates ferret occurrence relative to a UD (not counts) derived from locations of active burrow openings. If validated, the RSFs would increase the number of tools available to wildlife managers for fine-scale habitat evaluation for ferrets.

We evaluated the RSFs using data collected on the SC24 colony. Our objective was to determine usefulness of the RSFs in predicting the relative occurrence of ferrets inhabiting this adjacent, smaller prairie dog colony.

\section{Methods}

\section{Study Site}

We evaluated the ferret RSFs on the SC24 prairie dog colony of the Conata Basin, South Dakota, a site first inhabited by reintroduced ferrets in 1997 (Livieri 2006; approximate center of colony $\left.43^{\circ} 46^{\prime} 2.7^{\prime \prime} \mathrm{N}, 102^{\circ} 18^{\prime} 32.4^{\prime \prime} \mathrm{W}\right)$. The colony was characterized by western wheatgrass (Pascopyrum smithii), blue grama (Bouteloua gracilis), and buffalograss (Buchloe dactyloides), and was administered by the U.S. Department of Agriculture (USDA) Forest 
Service (Buffalo Gap National Grassland). Densities and distributions of burrow openings and colony size differed between SC24 (129.31 openings $\cdot \mathrm{ha}^{-1}$ ) and the SC07 colony of RSF development (144.69 openings $\cdot \mathrm{ha}^{-1}$ ). Additionally, monitored ferrets differed between the colonies; we found no evidence of uniquely identifiable adult ferrets moving between these neighboring colonies. Therefore, we assume independence of SC07 (the site of RSF development) and SC24 (the site of RSF evaluation).

\section{Predicting the Distribution of Black-footed Ferrets}

The year-specific (June-October 2007, JuneSeptember 2008) ferret RSFs were of the respective forms (Eads et al. 2011a),

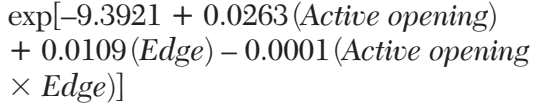

and

$$
\begin{aligned}
& \exp [-8.8321+0.0199(\text { Active opening }) \\
& +0.0092(\text { Edge })-0.0001 \text { (Active opening } \\
& \times E d g e)]
\end{aligned}
$$

To predict the relative probability of ferret occurrence, the RSFs require a map of active prairie dog burrow openings-throughout a colony or in nonoverlapping $80 \times 80$-m grid cells - and a delineated colony boundary. In 2005, during May-September, the general period of greatest prairie dog abundance and activity (Hoogland 1995), we recorded the locations of active prairie dog burrow openings $(n=23,983)$ on the SC24 colony using methods described by Jachowski et al. (2008) and Eads et al. (2011a, 2011b). We buffered locations of burrow openings by 20 -m-radius circular polygons, combined all polygons, and restricted the collective polygon by $20 \mathrm{~m}$ to delineate a colony boundary, as described by Eads et al. (2011b).

In ArcGIS ${ }^{\text {TM }}$ 9.2, we then established an 80 $\times 80$-m grid system that overlaid the SC24 colony map, as described above. We counted the number of active burrow openings in grid cells and then limited cells to those with $\geq 1$ burrow opening (Eads et al. 2011b). We also calculated the Euclidean distance from each grid cell center point to the nearest colony edge (Eads et al. 2011b).
We used the RSFs, the grid system data, and the raster calculator within ArcGIS ${ }^{\mathrm{TM}} 9.2$ to develop spatially explicit maps of the relative probability of occurrence of ferrets in the SC24 colony (Fig. 1). We classified predicted relative occurrence into 4-level, ordered factors based on quantiles, resulting in 4 classes for each RSF map (low, medium, high, and very high; Rittenhouse et al. 2007, Eads et al. 2011a). Quantile classification grouped grid cells into occurrence categories of nearly equal numbers of grid cells $(\mathrm{SD}=6.00)$.

\section{Collecting Independent Data on Black-footed Ferret Space}

During 17 June-14 October 2005 and 13 June-31 October 2006, we monitored 11 adult black-footed ferrets, including 3 animals monitored both years (Jachowski 2007), on nearly consecutive nights during spotlight searches concentrated between midnight and 06:00 (MDT; Biggins et al. 1986, Clark et al. 1986). Spotlight methods are described in Biggins et al. (2006a). Briefly, during each survey, an observer drove a vehicle and traversed a route that maximized spotlight coverage of the colony while minimizing overlap. Ferrets were each uniquely identifiable by an automated passive integrated transponder (PIT) tag reading or by a dye marking (see Jachowski 2007, Jachowski et al. 2011). We estimated adult ferret population size via trapping and processing of adult ferrets in July-August of both years and via intensive surveys throughout each field season (Biggins et al. 2006a). This assessment indicated that we monitored all resident adult ferrets inhabiting the colony.

\section{Evaluating the RSFs}

We used 2 measures to assess RSF performance: compositional analysis and presence count metrics (e.g., Eads et al. 2011b). We used compositional analysis (use vs. availability; Aebischer et al. 1993) to evaluate usefulness of the model in predicting (1) whether ferrets established home ranges in areas of certain predicted occurrence categories relative to the availability of these categories throughout the SC24 colony and (2) whether ferrets concentrated space use in areas of home ranges with certain predicted occurrence categories. The count metrics aided in evaluating model performance at used locations only; availability was not considered. 

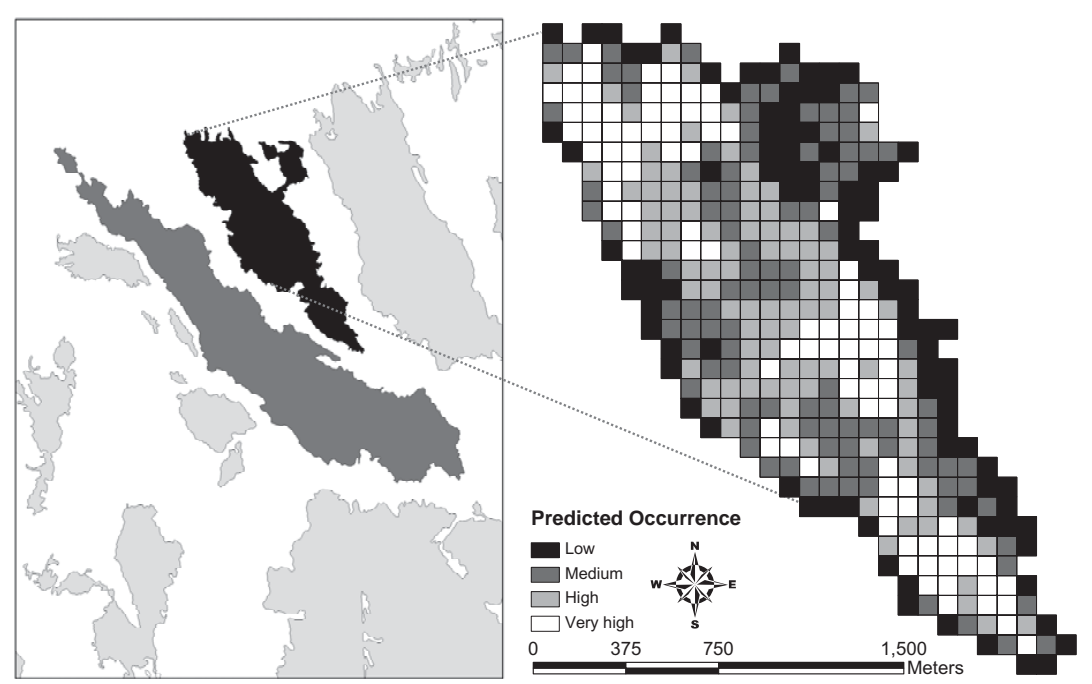

Fig. 1. Predicted, relative occurrence (4-level, ordered factor) of black-footed ferrets (Mustela nigripes) on SC24 (black polygon), a 227-ha black-tailed prairie dog (Cynomys ludovicianus) colony in the Conata Basin (inset map), Buffalo Gap National Grasslands, South Dakota. We derived projected ferret occurrence from resource selection functions (RSFs) developed on SC07 (dark gray polygon), a 452-ha colony (Eads et al. 2011b). Other colonies are depicted in light gray. The map of predicted occurrence depicts the 2007 RSF.

We assumed usefulness of the RSFs in predicting the relative occurrence of ferrets if ferrets intensively used areas of very high and high predicted occurrence.

COMPOSITIONAL ANALYSIS.-For compositional analysis, we included consecutive ferret locations separated by $\geq 12 \mathrm{~h}$ (e.g., Livieri 2007, Eads 2009). Insufficient sample size precluded home-range and core area estimation for 1 male ferret in 2005 and 1 female in 2006; however, we included these animals in countmetric evaluations. We assumed independence of home ranges and core areas of 1 male and 2 female ferrets monitored in both years; these ferrets inhabited a different area of the colony and were neighbored by different ferrets in 2005 and 2006.

We developed UD home ranges and Area Independent Method (AIM; Seaman and Powell 1990, Powell et al. 1997, Powell 2000) core areas for each ferret located $\geq 30$ times, within one season (Seaman et al. 1999, Millspaugh et al. 2006). We delineated UDs under a fixedkernel approach (Seaman and Powell 1996) in MATLAB $^{\circledR} 5.3$ (Mathworks Incorporated, Natick, MA), with bandwidth selected using the KDE folder (Beardah and Baxter 1995) and plug-in methods (Wand and Jones 1995, Jones et al. 1996, Gitzen et al. 2006). We delineated home-range boundaries as 95\% UD volume contours. An individual ferret's spaceuse pattern determined the AIM core area boundary. AIM core areas were delineated in the following step-by-step process: (1) we calculated a relative frequency of UD values by dividing raw UD point-values by the sum of all UD point-values; (2) we calculated the percentage of the maximum UD value for each UD point by dividing each value by the highest UD point-value (PCTPROB); (3) we ranked, from high to low, the UD points by PCTPROB values and defined the percentage of the home range represented by each UD value as the percentage of UD points having a value greater than or equal to the UD point under evaluation (PCTRANGE); (4) we plotted PCTRANGE versus PCTPROB and defined the AIM core area dividing point as "the point where the plot is maximally distant from a straight line with a slope of -1 , the slope of a distribution that cannot be distinguished from random use" (Seaman and Powell 1990: 245); and (5) we limited AIM core areas to UD points with PCTPROB values (and thus intensity of use values) greater than or equal to the value corresponding to the dividing point (Eads et al. 2011b). Because ferrets rarely use areas outside of prairie dog colonies (Biggins 


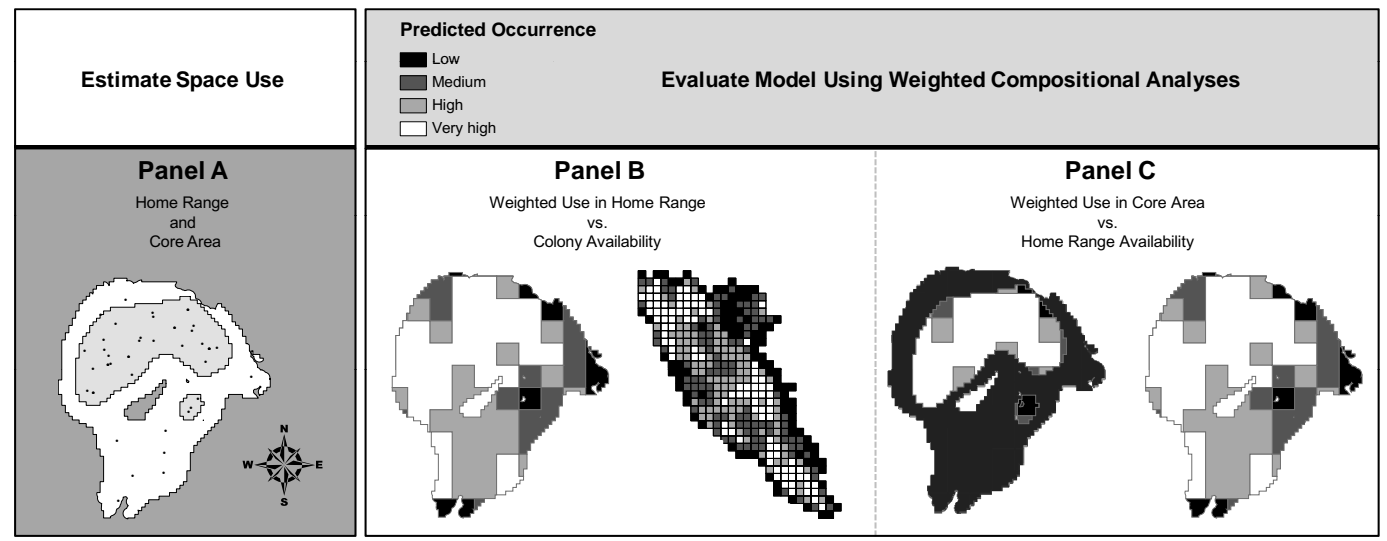

Fig. 2. We evaluated the resource selection functions (RSFs) in a step-by-step manner. First (Panel A), we used spotlight observations for uniquely identifiable black-footed ferrets (Mustela nigripes) to estimate utilization distribution home ranges and Area Independent Method core areas for each ferret inside the colony of black-tailed prairie dogs (Cynomys ludovicianus). In Panel A, a female ferret's locations are depicted as black dots, and the core area is delineated within the home range as a gray polygon. As depicted in Panel B, for each ferret, we overlaid the home range and core area on the RSF map of predicted relative occurrence (4-level, ordered factor). We used weighted compositional analysis to compare weighted home-range use of the 4 categories of predicted occurrence to availability of the categories at the scale of the colony. In addition, as denoted in Panel C, we compared weighted use within the core area to availability at the scale of the home range. Although not depicted here, we also calculated proportions of ferret locations (population level) that occurred within each of the 4 categories of predicted occurrence in order to calculate count-metric evaluations of the RSFs.

et al. 2006b), we clipped ferret home-range and core area estimates (UD grids and polygons) at the colony edge (Livieri 2007, Eads 2009).

To determine if the RSFs were useful in predicting where ferrets established home ranges, we compared home-range use to colony-level availability of the predicted occurrence categories (very high, high, medium, and low; Fig. 2). To determine if the RSFs were useful in predicting intensity of space use in home ranges, we compared core area use to home-range availability of the categories (Fig. 2). Both of these assessments were completed using weighted compositional analysis (Millspaugh et al. 2006). Within ferret home ranges and core areas, we calculated the proportion of UD volume in each predicted occurrence category. This approach provided a weighted UD estimate of use for each class of projected occurrence within home ranges and core areas, rather than assuming uniform use within home ranges and core areas (Millspaugh et al. 2006). We reclassified zero use as 0.30 , the minimum value that reduced type I error rates in simulation studies (see Bingham et al. 2007). We used a statistical significance threshold $(\alpha)$ of 0.10 for tests of selection and 0.05 for paired $t$ tests.
COUNT METRICS.-Using all locations for all monitored adult ferrets by year, we calculated count metrics (Fielding and Bell 1997) as the number of ferret locations occurring in areas of predicted occurrence (i.e., the very high and high categories) and the number of locations occurring in areas of predicted absence (i.e., medium and low). For each year of data, we conducted a Pearson's $\chi^{2}$ goodness of fit test, with Bonferroni correction, to determine if ferrets were observed in areas of some occurrence categories more often than expected (Neu et al. 1974). Expected proportions of observations in each category corresponded with the proportionate availability of each category.

\section{RESULTS}

In 2005 and 2006, we collected 349 and 296 confirmed observations of individual adult black-footed ferrets, respectively. We collected $\geq 30$ observations $(\bar{x}=48.27, \mathrm{SD}=10.94)$ of 5 ferrets in 2005 ( 5 females, 2 males) and 6 ferrets in 2006 ( 4 females, 2 males; 2 animals monitored both years). We used all animal locations collected in 2005 ( $n=8$ ferrets) and 2006 ( $n=7$ ferrets $)$ in count-metric evaluations ( 3 animals monitored both years). 


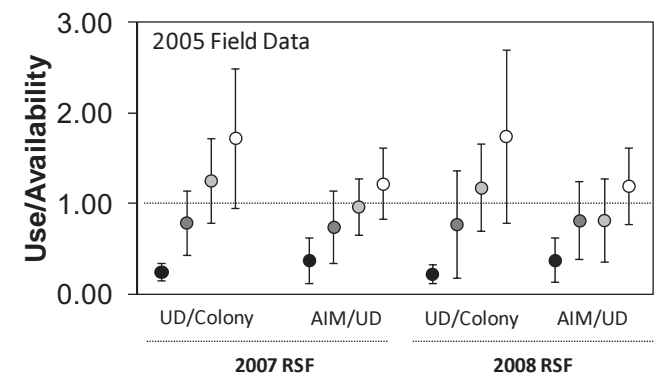

Fig. 3. Average proportional use divided by availability (bars represent standard deviation) for 4 classes of predicted black-footed ferret (Mustela nigripes) occurrence on a black-tailed prairie dog (Cynomys ludovicianus) colony in the Conata Basin, Buffalo Gap National Grasslands, South Dakota (low = black, medium = dark gray, high $=$ gray, and very high $=$ white). Predicted occurrence was derived from resource selection functions developed on a separate colony in 2007 and 2008. Home-range (utilization distribution, UD) and Area Independent Method (AIM) core area use were estimated for ferrets $(n=7)$ monitored during 17 June-14 October 2005. Availability was defined at the colony level (colony) and home range (UD) level. If proportional use equaled proportional availability, then the resulting value would be 1.00 . Values above 1.00 indicate selection for that predicted occurrence category.

\section{Field Data}

The 2007 RSF was useful in predicting the distribution of ferrets and ferret occurrence in 2005. A comparison between colony-wide availability and use within home ranges demonstrated selection rankings (high to low) of very high, high, medium, and low (Wilk's $\lambda$ $\left.=0.06, \chi_{3}^{2}=13.72, P=0.003\right)$. The very high and high classes were selected over all other classes; the medium class was selected over the low class (Fig. 3). A comparison between home-range availability and core area use demonstrated occurrence rankings of very high, high, medium, and low (Wilk's $\lambda=$ $\left.0.11, \chi_{3}^{2}=10.83, P=0.013\right)$. The very high and high classes were selected over the low class (Fig. 3). For all ferret locations, 80.23\% occurred in areas of very high or high predicted occurrence. Ferrets were observed more often than expected in areas of very high and high predicted occurrence and less often than expected in areas of low and medium predicted occurrence (Table 1).

The 2008 RSF was also useful in 2005. A comparison between colony-wide availability and use within home ranges demonstrated selection rankings (high to low) of very high,

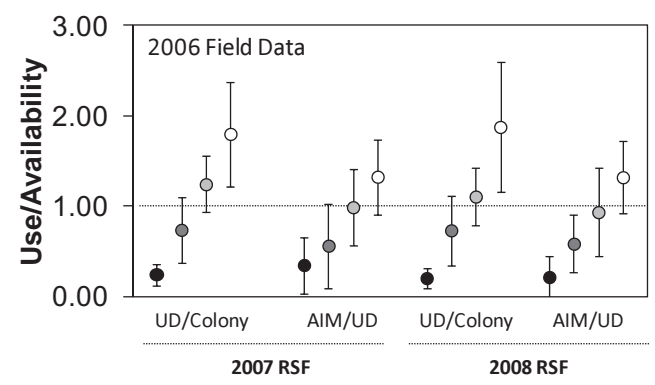

Fig. 4. Average proportional use divided by availability (bars represent standard deviation) for 4 classes of predicted black-footed ferret (Mustela nigripes) occurrence on a black-tailed prairie dog (Cynomys ludovicianus) colony in the Conata Basin, Buffalo Gap National Grasslands, South Dakota (low = black, medium = dark gray, high = gray, and very high $=$ white). Predicted occurrence was derived from resource selection functions developed on a separate colony in 2007 and 2008. Home-range (utilization distribution, UD) and Area Independent Method (AIM) core area use were estimated for ferrets $(n=6)$ monitored during 13 June-31 October 2006. Availability was defined at the colony level (colony) and home range, UD level. If proportional use equaled proportional availability, then the resulting value would be 1.00 . Values above 1.00 indicate selection for that predicted occurrence category.

high, medium, and low (Wilk's $\lambda=0.09, \chi^{2}{ }_{3}$ $=11.99, P=0.007)$. The very high and high classes were selected over the low class (Fig. 3). A comparison between home-range availability and core area use demonstrated occurrence rankings of very high, high, medium, and low (Wilk's $\lambda=0.24, \chi^{2}{ }_{3}=7.22, P=$ $0.065)$. The very high class was selected over the low class (Fig. 3). For all ferret locations, $80.52 \%$ occurred in areas of very high or high predicted occurrence. Ferrets were observed more often than expected in areas of very high and high predicted occurrence and less often than expected in areas of low and medium predicted occurrence (Table 1).

\section{Field Data}

The 2007 RSF was useful at the colony scale in 2006. A comparison between colonywide availability and use within home ranges demonstrated selection rankings of high, very high, medium, and low (Wilk's $\lambda=0.08, \chi^{2}{ }_{3}$ $=15.09, P=0.002)$. The very high, high, and medium classes were selected over the low class (Fig. 4). Selection for certain categories of predicted occurrence was not evident within home ranges (Wilk's $\lambda=0.39, \chi^{2}{ }_{3}=$ 
TABLE 1. Proportions of expected locations of black-footed ferrets (Mustela nigripes) in 4 classes of predicted occurrence derived from 2 resource selection function models (2007 and 2008) developed at another black-tailed prairie dog (Cynomys ludovicianus) colony. Ferrets were monitored during 17 June-14 October 2005 and 13 June-31 October 2006. The proportion of observed locations in a predicted occurrence category was less than expected if the expected proportion was above the Bonferroni-corrected confidence interval (CI) for the observed locations (expected > observed CI). In contrast, the proportion of observed locations was greater than expected if the expected proportion was below the CI for the observed locations (expected < observed CI). In all cases, the very high and high categories were used more than expected, and the medium and low classes were used less than expected.

\begin{tabular}{|c|c|c|c|c|c|}
\hline \multirow[b]{2}{*}{ Category } & \multirow[b]{2}{*}{ Expected } & \multicolumn{2}{|c|}{$2007 \mathrm{RSF}$} & \multicolumn{2}{|c|}{$2008 \mathrm{RSF}$} \\
\hline & & 2005 CI & 2006 CI & 2005 CI & 2006 CI \\
\hline Low & 0.22 & $0.00-0.05$ & $0.00-0.04$ & $0.00-0.04$ & $0.00-0.03$ \\
\hline Medium & 0.28 & $0.12-0.22$ & $0.13-0.23$ & $0.12-0.22$ & $0.10-0.20$ \\
\hline High & 0.25 & $0.29-0.42$ & $0.30-0.43$ & $0.30-0.43$ & $0.26-0.38$ \\
\hline Very high & 0.25 & $0.38-0.51$ & $0.37-0.51$ & $0.38-0.51$ & $0.45-0.58$ \\
\hline
\end{tabular}

5.68, $P=0.128$; Fig. 4). For all ferret locations, $81.08 \%$ occurred in areas of very high or high predicted occurrence. Ferrets were observed more often than expected in areas of very high and high predicted occurrence and less often than expected in areas of low and medium predicted occurrence (Table 1).

The 2008 RSF was also useful in 2006. A comparison between colony-wide availability and use within home ranges demonstrated selection rankings of high, very high, medium, and low (Wilk's $\lambda=0.05, \chi_{3}^{2}=17.41, P=$ $0.0006)$. The very high and high classes were selected over the medium and low classes (Fig. 4). A comparison between home-range level availability and core area use demonstrated selection rankings of high, very high, medium, and low (Wilk's $\lambda=0.14, \chi^{2}{ }_{3}=$ 11.70, $P=0.009)$. The very high, high, and medium classes were selected over the low class (Fig. 4). For all ferret locations, 83.45\% occurred in areas of very high or high predicted occurrence. Ferrets were observed more often than expected in areas of very high and high predicted occurrence and less often than expected in areas of low and medium predicted occurrence (Table 1).

\section{Discussion}

The RSFs were useful in predicting the relative distribution of black-footed ferrets in a separate prairie dog colony. Thus, 3 resource selection models (i.e., the RUF and 2 RSFs) are useful in predicting fine-scale distributions of the ferret, at least in the Conata Basin. The models are based on alternative working hypotheses (Chamberlin 1890). The RSFs predict the relative probability of ferret occur- rence in $80 \times 80$-m grid cells; the underlying hypothesis is that, within a prairie dog colony, the collective ferret population responds to spatial variation in densities of active burrow openings at this scale and that ferrets select areas of high burrow opening density, particularly at colony edges. In contrast, grid cell size of a ferret RUF map depends on the distribution of active burrow openings; the underlying hypothesis is that ferrets select areas with relatively high densities of active burrow openings and generally avoid colony edges (Jachowski et al. 2011). It would be helpful to compare performance of the RSFs and RUF at multiple sites. It is important to note that each approach might better meet different objectives because RSFs predict relative occurrence of ferrets whereas RUFs predict unconditional occurrence. We encourage evaluation of all 3 models. However, in some cases, use of the RUF could be limited, because an entire colony must be mapped to generate a map of predicted occurrence for ferrets. In contrast, the RSFs do not require a complete map; the RSFs can be implemented with maps or counts of burrow openings in $80 \times 80$-m grid cells, permitting a more flexible approach. If entire colonies can be mapped, managers can evaluate all 3 models. If only portions of a site can be mapped, then the RSFs can still be evaluated (e.g., by counting numbers of active burrow openings in randomly selected grid cells, using the RSFs to predict the relative occurrence of ferrets in the cells, and then counting numbers of ferret observations in the cells to determine if ferret resource selection corresponded with the predictions).

To further evaluate the models, we encourage managers to use the RSFs and RUF in an 
experimental context, if possible. The models can be used to predict the relative (RSFs) or unconditional probability (RUF) of ferret occurrence throughout prairie dog colonies (RSFs and RUF) or in portions of colonies (RSFs). For instance, if ferrets are still released to a site, as is the case at most reintroduction sites (Jachowski and Lockhart 2009), then some ferrets can be released to areas estimated as very high predicted occurrence, while other ferrets are released to areas estimated as low predicted occurrence (Chipault [2010] used a similar experimental approach). If free-ranging ferrets inhabited the site before the current release, those ferrets and the released ferrets can be monitored. The evaluation could involve analyses of space-use data, as completed herein, but also comparisons of survival and offspring production among ferrets released to or already inhabiting areas with different predicted occurrence categories. Ideally, a ferret-habitat model would predict not only distributions of ferrets but also the fitness consequences of resources (Van Horne 1983, Johnson 2007, Shifley et al. 2009).

Where applicable, the RSFs and RUF could complement habitat evaluation procedures for ferrets. The quality of a complex of colonies can be estimated, as carrying capacity, with relative ease using the bioenergetics model (Biggins et al. 1993). If the RSFs or RUF are useful at a focal complex, as found for the Conata Basin, burrow openings could be mapped in colonies (RSFs and RUF) or in areas of colonies (RSFs). The models could then be used to predict ferret occurrence. Releases could then be further prioritized, perhaps in an experimental context, as discussed above. Also, efforts to enhance prairie dog habitat can be concentrated in areas of low and medium predicted occurrence to increase the numbers of prairie dogs and burrow openings (i.e., to increase densities of prey and refuge for ferrets).

To use the RSFs and RUF, a map of active burrow openings is required. Mapping effort is labor- and time-intensive. For instance, in Montana, individuals mapped 175 prairie dog burrow openings per hour on average (Matchett 1994). In 2005 at the SC24 colony, 29,312 burrow openings were mapped. Assuming similar speeds of mapping, the 2005 effort required at least 167.50 hours (i.e., 21 eighthour work days; exact hours not recorded).
Many ferret sites have thousands of hectares of habitat and potential ferret habitat involves tens of thousands of hectares in numerous states (Ernst et al. 2006), requiring seemingly prohibitive investments for these kinds of evaluations. Therefore, pragmatic considerations presently inhibit universal use of the RUF, which requires maps of entire colonies. As discussed above, the RSFs are more flexible, only requiring maps or counts of burrow openings in grid cells instead of maps of burrow openings throughout entire colonies. Thus, at this time the RSFs could be used at least in portions of many sites-for instance, when dusting burrow openings with insecticides to control flea populations and outbreaks of plague (e.g., Seery et al. 2003). Assuming an individual can map and dust 175 burrow openings per hour (Matchett 1994), at the SC24 colony an individual could have mapped 20 randomly selected cells in one 8-hour work day (i.e., days $=0.0511 \times$ number of cells).

A quick and relatively inexpensive means of burrow mapping would facilitate use of the ferret RSFs and RUF at large spatial scales. Remote-sensing could prove useful for these purposes; satellite images have been used to map great gerbil (Rhombomys opimus) burrow openings in Kazakhstan (Addink et al. 2010). Aerial images of the Conata Basin were collected in 2005 and 2007, years in which prairie dog burrow openings were mapped (Jachowski 2007 and Eads 2009, respectively). An automated burrow mapping method could perhaps be calibrated and used with the ferret RSFs and RUF as a cost-effective method to predict fine-scale ferret distributions at large scales (e.g., throughout entire prairie dog colonies and complexes of prairie dog colonies).

\section{ACKNOWLEDGMENTS}

This study was made possible through State Wildlife Grant T35, study number 2435, provided by the South Dakota Department of Game, Fish and Parks. Support was also provided by the National Fish and Wildlife Foundation (Grant number 2006-0058-0000) and the University of Missouri. Logistical and field support were provided by the U.S. Fish and Wildlife Service, the USDA Forest Service, the U.S. Geological Survey, and Prairie Wildlife Research. Thanks to D. Hansen and R. Jachowski for assistance with spotlight surveys, and 
R. Jachowski for assistance with mapping burrow openings. Thanks to T. Bonnot, H. He, M. Gompper, M. Lockhart, and C. Rittenhouse for productive discussions, and to D. Albertson, K. Atchley, B. Perry, and D. Sargent for assistance in numerous objectives. Thanks also to S. Grassel and J. Stabach for constructive comments and reviews of a previous draft of the manuscript.

Any use of trade, product, or firm names is for descriptive purposes only and does not imply endorsement by the U.S. federal government.

\section{Literature Cited}

Addink, E.A., S.M. De Jong, S.A. Davis, V. DubyanskiY, L.A. Burdelov, And H. Leirs. 2010. The use of high-resolution remote sensing for plague surveillance in Kazakhstan. Remote Sensing of Environment 114:674-681.

Aebischer, N.J., P.A. Roberston, and R.E. Kenward. 1993. Compositional analysis of habitat use from animal radio-tracking data. Ecology 74:1313-1325.

BEARDAH, C.C., AND M.J. BaXTER, EDITORS. 1995. MAT$\mathrm{LAB}$ routines for kernel density estimation and the graphical representation of archaeological data. Leiden University, Rapenburg, The Netherlands.

Biggins, D.E., J.L. Godbey, M.R. Matchett, L.R. Hanebury, T.M. Livieri, and P.E. Marinari. 2006a. Monitoring black-footed ferrets during reestablishment of free-ranging populations: discussion of alternative methods and recommended minimum standards. Pages 155-174 in J.E. Roelle, B.J. Miller J.L. Godbey, and D.E. Biggins, editors, Recovery of the black-footed ferret: progress and continuing challenges. U.S. Geological Survey Scientific Investigations Report 2005-5293.

Biggins, D.E., J.L. Godbey, M.R. Matchett, and T.M. LIVIERI. 2006b. Habitat preferences and intraspecific competition in black-footed ferrets. Pages 129 140 in J.E. Roelle, B.J. Miller, J.L. Godbey, and D.E. Biggins, editors, Recovery of the black-footed ferret: progress and continuing challenges. U.S. Geological Survey Scientific Investigations Report 2005-5293.

Biggins, D.E., J.M. Lockhart, And J.L. Godbey. 2006c. Evaluating habitat for black-footed ferrets: revisions of an existing model. Pages 143-150 in J.E. Roelle, B.J. Miller, J.L. Godbey, and D.E. Biggins, editors, Recovery of the black-footed ferret: progress and continuing challenges. U.S. Geological Survey Scientific Investigations Report 2005-5293.

Biggins, D.E., B. Miller, L. Hanebury, R. Oakleaf, A Farmer, R. Crete, and A. Dood. 1993. A technique for evaluating black-footed ferret habitat Pages 73-78 in J. Oldemyer, B. Miller, and R. Crete, editors, Management of prairie dog complexes for reintroduction of the black-footed ferret. U.S. Fish and Wildlife Service Biological Report 13.

Biggins, D.E., M. Schroeder, S. Forrest, and L. RICHARDSON. 1985. Movements and habitat relationships of radio-tagged black-footed ferrets. Pages 11.1-11.17 in S.H. Anderson and D.B. Inkley, editors, Black-footed Ferret Workshop Proceedings,
18-19 September 1984. Wyoming Game and Fish Department, Cheyenne, WY.

1986. Activity of radio-tagged black-footed ferrets. Great Basin Naturalist Memoirs 8:135-140.

Bingham, R.L., L.A. Brennan, AND B.M. BaLlard. 2007. Misclassified resource selection: compositional analysis and unused habitat. Journal of Wildlife Management 71:1369-1374.

Chamberlin, T.C. 1890. The method of multiple working hypotheses. Science 15:92-96.

Chipault, J.G. 2010. Fine-scale habitat use by black-footed ferrets (Mustela nigripes) released on black-tailed prairie dog (Cynomys ludovicianus) colonies in New Mexico. Master's thesis, Colorado State University, Fort Collins, CO.

Clark, T.W., L. Richardson, S.C. Forrest, D.E. Casey, AND T.M. CAMPBELL. 1986. Descriptive ethology and activity patterns of black-footed ferrets. Great Basin Naturalist Memoirs 8:115-134.

Conroy, M.J., And C.T. Moore. 2002. Wildlife habitat modeling in an adaptive framework: the role of alternative models. Pages 205-218 in J.M. Scott, P.J. Heglund, M.L. Morrison, J.B. Haufler, M.G. Raphael, W.A. Wall, and F.B. Samson, editors, Predicting species occurrences: issues of accuracy and scale. Island Press, Washington, DC.

EADS, D.A. 2009. Evaluation and development of blackfooted ferret resource selection models. Master's thesis, University of Missouri, Columbia, MO.

Eads, D.A., J.J. Millspaugh, D.E. Biggins, D.S. JachowSKI, AND T.M. LIVIERI. 2011a. Evaluation of a blackfooted ferret resource utilization function model. Journal of Wildlife Management 75:1155-1163.

Eads, D.A., J.J. Millspaugh, D.E. Biggins, T.M. Livieri, AND D.S. JACHOWSKI. 2011b. Post-breeding resource selection by adult black-footed ferrets in the Conata Basin, South Dakota. Journal of Mammalogy 92: 760-770.

Ernst, A.E., A.L. Clark, And D.R. Gober. 2006. Ferret recovery among jurisdictional entities. Pages 89-95 in J.E. Roelle, B.J. Miller, J.L. Godbey, and D.E. Biggins, editors, Recovery of the black-footed ferret: progress and continuing challenges. U.S. Geological Survey Scientific Investigations Report 2005-5293.

FieldiNG, A.H., AND J.F. BELL. 1997. A review of methods for the assessment of prediction errors in conservation presence/absence models. Environmental Conservation 24:38-49.

Gitzen, R.A., J.J. Millspaugh, and B.J. Kernohan. 2006. Bandwidth selection for fixed kernel analysis of animal range use. Journal of Wildlife Management 70:1334-1344.

HoogLand, J.L. 1995. The black-tailed prairie dog: social life of a burrowing mammal. Chicago University Press, Chicago, IL.

JACHOWSKI, D.S. 2007. Resource selection by black-footed ferrets in relation to the spatial distribution of prairie dogs. Master's thesis, University of Missouri, Columbia, MO.

JACHOWSKI, D.S., AND J.M. LOCKHART. 2009. Reintroducing the black-footed ferret Mustela nigripes to the Great Plains of North America. Small Carnivore Conservation 41:58-64.

Jachowski, D.S., J.J. Millspaugh, D.E. Biggins, T.M. LiVIERI, AND M.R. MATCHETT. 2008. Implications of black-tailed prairie dog spatial dynamics to blackfooted ferrets. Natural Areas Journal 28:14-25. 
Jachowski, D.S., J.J. Millspaugh, D.E. Biggins, T.M. Livieri, M.R. Matchett, and C.D. RitTenhouse. 2011. Resource selection by black-footed ferrets in South Dakota and Montana. Natural Areas Journal 31:218-225.

Johnson, C.J., D.R. SeIP, And M.S. Boyce. 2004. A quantitative approach to conservation planning: using resource selection functions to map the distribution of mountain caribou at multiple spatial scales. Journal of Applied Ecology 41:238-251.

Johnson, D.H. 2001. Validating and evaluating models. Pages 105-122 in T.M. Shenk and A.B. Franklin, editors, Modeling in natural resource management: development, interpretation, and application. Island Press, Washington, DC.

Johnson, M.D. 2007. Measuring habitat quality: a review. Condor 109:489-504.

Jones, M.C., J.S. Marron, and S.J. Sheather. 1996. A brief survey of bandwidth selection for density estimation. Journal of the American Statistical Association 91:401-407.

LiviERI, T.M. 2006. Ten-year history of the Conata Basin black-footed ferret population: 1996-2005. Prairie Wildlife Research, Wall, SD.

2007. Black-footed ferret spatial use of prairie dog colonies in South Dakota. Master's thesis, University of Wisconsin, Stevens Point, WI.

Manly, B.F.J., L.L. McDonald, D.L. Thomas, T.L. McDonALD, AND W.P. ERICKSON. 2002. Resource selection by animals: statistical design and analysis for field studies. Kluwer Academic Publishers, Secaucus, NJ.

Marinari, P.E., and J.S. Kreeger. 2006. An adaptive management approach for black-footed ferrets in captivity. Pages 23-27 in J.E. Roelle, B.J. Miller, J.L. Godbey, and D.E. Biggins, editors, Recovery of the black-footed ferret: progress and continuing challenges. U.S. Geological Survey Scientific Investigations Report 2005-5293.

Matchett, R. 1994. 1994 Prairie dog burrow mapping with global positioning systems, UL Bend National Wildlife Refuge, Phillips County, Montana. U.S. Fish and Wildlife Report. 5 pp.

Miller, B., D. Biggins, L. Hanebury, and A. Vargas. 1994. Reintroductions of the black-footed ferret (Mustela nigripes). Pages 455-464 in P.J.S. Olney, G.M. Mace, and A.T.C. Feistner, editors, Creative conservation: interactive management of wild and captive animals. Chapman and Hall, London, United Kingdom.

Millspaugh, J.J., AND J.M. Marzluff. 2001. Radio-tracking and animal populations: past trends and future needs. Pages 383-393 in J.J. Millspaugh and J.M. Marzluff, editors, Radio-tracking and animal populations. Academic Press, San Diego, CA.

Millspaugh, J.J., R.M. Nielson, L. McDonald, J.M. Marzluff, R.A. Gitzen, C.D. RitTenhouse, M.W. Hubbard, and S.L. Sheriff. 2006. Analysis of resource selection using utilization distributions. Journal of Wildlife Management 70:384-395.

Millspaugh, J.J., AND F.R. ThOMPSOn III, EDitors. 2009. Models for planning wildlife conservation in large landscapes. Elsevier Science, San Diego, CA.
Morrison, M.L., B.C. Marcot, and R.W. Mannan. 1998. Wildlife-habitat relationships. 2nd edition. University of Wisconsin Press, Madison, WI.

Neu, C.W., C.R. Byers, and J.M. Peek. 1974. A technique for analysis of utilization-availability data. Journal of Wildlife Management 38:541-545.

PowELL, R.A. 2000. Animal home ranges and territories and home range estimators. Pages 65-110 in L. Boitani and T.K. Fuller, editors, Research techniques in animal ecology: controversies and consequences. Columbia University Press, New York, NY.

Powell, R.A., J.W. Zimmerman, and D.E. Seaman. 1997. Ecology and behaviour of North American black bears: home ranges, habitat and social organization. Chapman and Hall, London, United Kingdom.

Power, M. 1992. The predictive validation of ecological and environmental models. Ecological Modelling 68:33-50.

Rittenhouse, C.D., J.J. Millspaugh, A.B. Cooper, M.W. Hubbard, S.L. Sheriff, and R.A. Gitzen. 2007. Modeling resource selection using polytomous logistic regression and kernel density estimates. Environmental and Ecological Statistics 15:39-47.

Rykiel, E.J., JR. 1996. Testing ecological models: the meaning of validation. Ecological Modelling 90: 229-244.

Seaman, D.E., J.J. Millspaugh, B.J. Kernohan, G.C. Brundige, K.J. RaEdeke, and R.A. GitZen. 1999. Effects of sample size on kernel home range estimates. Journal of Wildlife Management 63:739-747.

Seaman, D.E., and R.A. Powell. 1990. Identifying patterns and intensity of home range use. International Conference on Bear Research and Management 8: 243-249.

1996. An evaluation of the accuracy of kernel density estimators for home range analysis. Ecology 77: 2075-2085.

Seery, D.B., D.E. Biggins, J.A. Montenieri, R.E. Enscore, D.T. TANDA, AND K.L. Gage. 2003. Treatment of black-tailed prairie dog burrows with deltamethrin to control fleas (Insecta: Siphonaptera) and plague. Journal of Medical Entomology 40: 718-722.

Shifley, S., C.D. Rittenhouse, and J.J. Millspaugh. 2009. Validation of landscape simulation models that predict vegetation and wildlife dynamics. Pages 415-448 in J.J. Millspaugh and F.R. Thompson III, editors, Models for planning wildlife conservation in large landscapes. Elsevier Science, San Diego, CA.

VAN HoRne, B. 1983. Density as a misleading indicator of habitat quality. Journal of Wildlife Management 47:893-901.

WAND, M.P., AND M.C. JoNEs. 1995. Kernel smoothing. Chapman and Hall, London, United Kingdom.

Williams, E.S., E.T. Thorne, D.R. KwiatKowski, S.L. ANDERSON, AND K. LUTZ. 1991. Reproductive biology and management of captive black-footed ferrets (Mustela nigripes). Zoo Biology 10:383-398.

Received 18 April 2011 Accepted 13 February 2012 